NBER WORKING PAPER SERIES

\title{
THE GROWTH IN THE SOCIAL SECURITY DISABILITY ROLLS: A FISCAL CRISIS UNFOLDING
}

\author{
David Autor \\ Mark Duggan \\ Working Paper 12436 \\ http://www.nber.org/papers/w12436 \\ NATIONAL BUREAU OF ECONOMIC RESEARCH \\ 1050 Massachusetts Avenue \\ Cambridge, MA 02138 \\ August 2006
}

The authors thank Amy Finkelstein, James Hines, Timothy Taylor and Michael Waldman for suggestions that substantially improved the manuscript, and Alex Chernyakov and Kathleen Cui for excellent research assistantship. Autor acknowledges financial support from the National Science Foundation (CAREER SES-0239538) and Duggan from the Alfred P. Sloan Foundation. The views expressed herein are those of the author(s) and do not necessarily reflect the views of the National Bureau of Economic Research.

(C2006 by David Autor and Mark Duggan,. All rights reserved. Short sections of text, not to exceed two paragraphs, may be quoted without explicit permission provided that full credit, including $\odot$ notice, is given to the source. 
The Growth in the Social Security Disability Rolls: A Fiscal Crisis Unfolding

David Autor and Mark Duggan

NBER Working Paper No. 12436

August 2006

JEL No. H53, H55, I12, I18, J26

\begin{abstract}
More than 80 percent of nonelderly U.S. adults are insured against the risk of disabling physical or mental illness by Social Security Disability Insurance (SSDI). This article evaluates the causes of the extraordinary growth in SSDI enrollment, considers its fiscal ramifications, and discusses potential policy responses. While aggregate population health has improved by most measures in recent decades, the rate of SSDI receipt among nonelderly adults has nearly doubled since 1984. We project that SSDI receipt will rise by an additional seventy percent before reaching a steady state rate of approximately 6.5 percent of adults between the ages of 25 and 64, with cash benefit payments exceeding $\$ 150$ billion annually (excluding Medicare).

We trace the rapid expansion of SSDI to: (1) congressional reforms to disability screening in 1984 that enabled workers with low mortality disorders such as back pain, arthritis and mental illness to more readily qualify for benefits; (2) a rise in the after-tax DI income replacement rate, which strengthened the incentives for workers to seek benefits; (3) and a rapid increase in female labor force participation that expanded the pool of insured workers. Notably, the aging of the baby boom generation has contributed little to the growth of SSDI to date.

Among several avenues for reducing SSDI growth, we suggest that the most promising are revamping the disability appeals process--in which the Social Security Administration currently loses nearly three-quarters of all appeals--and reducing the attractiveness of DI benefits for work-capable disabled individuals by providing additional access to public health insurance. By contrast, previous efforts to reduce the SSDI rolls by discontinuing benefits or by providing stronger return-to-work incentives have proved remarkably unsuccessful.
\end{abstract}

David Autor

Department of Economics

MIT, E52-371

50 Memorial Drive

Cambridge, MA 02142-1347

and NBER

dautor@mit.edu
Mark Duggan

University of Maryland

Department of Economics

3115L Tydings Hall

College Park, MD 20742

and NBER

duggan@econ.bsos.umd.edu 
More than 80 percent of all nonelderly adults in the United States are insured against the risk of being unable to work because of a physical or mental disability by the Social Security Disability Insurance (DI) program. To be insured for DI benefits, a person must have worked in a job covered by Social Security in at least five of the ten most recent years. To be awarded benefits, an individual must have a medically determinable physical or mental impairment that is expected to result in death or to last for at least a year and that prevents the person from engaging in a "substantial gainful activity."

During the past two decades, the fraction of individuals receiving Disability Insurance benefits has grown substantially, as shown in Figure 1. In 1985, 2.2 percent of individuals between the ages of 25 and 64 were receiving DI benefits, but by 2005 this fraction had risen to 4.1 percent. If recent entry and exit rates continue in the years ahead, then more than 6 percent of the nonelderly adult population will soon be receiving DI benefits.

The rapid expansion of the beneficiary population has three main causes. First, a set of congressional reforms in 1984 to Disability Insurance screening led to rapid growth in the share of recipients suffering from back pain and mental illness. Because these disorders have comparatively low mortality, the average duration of disability spells—and hence the size of the recipient population—has increased. Second, a rise in the after-tax DI income replacement ratethat is, the ratio of disability income to former labor earnings—strengthened the incentives for workers to seek benefits. Third, a rapid increase in female labor force participation expanded the pool of insured workers. The aging of the baby boom generation has contributed little to the rise of receipt of disability benefits, while improvements in population health have likely reduced the incidence of disabling medical disorders.

The growth in Disability Insurance receipt has substantial fiscal ramifications for the 
health of the Social Security system and the federal budget as a whole. Since 1985, the fraction of Social Security spending accounted for by the DI program rose from 10 to 17 percent and the payroll tax devoted to DI increased from 1.0 percent to 1.8 percent. Real expenditures on the DI program have increased more rapidly than enrollment. In 2005, the Social Security Administration disbursed $\$ 85.4$ billion to 6.5 million DI recipients and their families. Most of these benefits went to disabled persons, with almost $\$ 6$ billion paid to the 1.6 million eligible children of DI recipients and an additional $\$ 0.5$ billion paid to the 0.16 million eligible spouses of DI recipients.

More than 832,000 persons were newly awarded Disability Insurance benefits in 2005. To gauge the fiscal commitment these awards entail, consider an average case: a 50-year-old DI awardee who has a constant 3.1 percent annual mortality rate, receives an average monthly benefits equal to $\$ 1100$, and only receives DI benefits until age 66 (when Social Security retirement benefits kick in). If future benefits are discounted at a real 2 percent annual rate, the present value of this average DI award is $\$ 150,000$. This implies that the 832,000 DI awards made during the 2005 calendar year had a present value of approximately \$125 billion. DI recipients are also eligible for health insurance through the Medicare program. The cost of providing this care was $\$ 49$ billion during the 2005 fiscal year, which amounted to $\$ 7,700$ per recipient. Taking into account the value of these benefits until age 65 (after which the time claimant would become eligible for Medicare even without a DI award), the present value of federal spending for the average DI awardee increases to more than $\$ 245,000 .{ }^{1}$ Using current

\footnotetext{
${ }^{1}$ This calculation assumes that the real value of Disability Insurance benefits remains constant for 16 years and 4 months (a 50-year old born in 1956 would have a full retirement age of 66 and 4 months), which seems reasonable given that benefits are adjusted each year by the growth in the Consumer Price Index. Medicare spending per recipient is assumed to grow at 2.3 percent per year, the average rate from 2003 to 2005, though only the first 15 years are considered because the person would otherwise have been eligible on his or her $65^{\text {th }}$ birthday.
} 
population and cost figures, the steady-state cost of these benefits is $\$ 204$ billion dollars

annually, equal to 8.1 percent of the $\$ 2.5$ trillion federal budget in 2005 and five times the cost of the federal Department of Homeland Security. While the rate of DI receipt is lower in the United States than in other developed Western economies, the American program has grown dramatically over the last 20 years in size and expense. ${ }^{2}$ This growth poses significant risks to the finances of the DI program and the broader Social Security system, and raises troubling questions as to whether the program is being misused by claimants.

This article begins by providing an overview of the Disability Insurance program, describing who qualifies for the program, how an individual applies for benefits and how the level of benefits is determined. ${ }^{3}$ Next, we summarize the factors that are responsible for the growth in the DI rolls and discuss how the characteristics of DI recipients have changed as a result. We then explore the extent of moral hazard in the DI program and the effectiveness of the screening process in distinguishing meritorious from nonmeritorious claims. The subsequent section identifies the challenges that the DI program creates for Social Security finances and Social Security reform. In the final section, we discuss potential reforms to the DI program. An overarching issue raised by our discussion is that five decades of congressional reforms and extensions of Disability Insurance have left the program with an ill-defined mission. Although the program nominally exists to insure workers' labor income against disabling medical events, the DI screening procedure put in place by Congress hinges to a significant extent on an applicant's employability, not just personal health, causing the program to function

\footnotetext{
${ }^{2}$ According to OECD (2003), the fraction of nonelderly adults receiving disability benefits is significantly lower in the U.S. than in most other industrialized countries. The average rate of enrollment among adults ages 20 to 64 in other OECD-17 countries is 6.5 percent versus 4.5 percent in the United States. Additionally the ratio of average disability benefits to per-capita wages in 1999 was lower in the United States than in any other OECD-17 country.

${ }^{3}$ The federal government provides disability insurance through other programs, too. For example, the means-tested Supplemental Security Income (SSI) program paid disability benefits to 4.1 million non-elderly adults, 1.0 million children, and 800,000 elderly adults in 2004. The other major programs are administered by the Department of Veterans Affairs, which currently pays benefits to more than 3.0 million veterans of military service.
} 
much like a long-term unemployment insurance program for the unemployable. Ultimately, we believe that Congress must clarify whether the primary social objective of the DI program is to provide disability insurance or to provide employability insurance—and if the former, to revise the selection criteria accordingly. Short of this objective, we suggest below that the two most promising near-term opportunities for reform entail revamping the disability appeals process—in which the Social Security Administration currently loses nearly three-quarters of all appealsand reducing the attractiveness of DI benefits for work-capable disabled individuals by providing additional access to public health insurance.

\section{The Social Security Disability Insurance Program}

Social Security began paying monthly retirement benefits to workers over the age of 65 in 1940, but disability benefits were not added until 1956. At their introduction, Congress conceived of disability benefits as providing early retirement insurance for the "totally and permanently disabled," to use the phrasing of the 1950 grant-in-aid program for state public assistance on which the Disability Insurance program was based. As such, benefits were limited to the near-elderly, ages 50 to 64 , who were unable to "engage in any substantial gainful activity by reason of any medically determinable physical or mental impairment which can be expected to result in death or to be of long-continued and indefinite duration.” Disabled adult children of deceased, retired or disabled workers could also qualify for DI if they had become disabled before reaching the age of 18 .

During the next 30 years, the narrow scope of the Disability Insurance program was 
broadened substantially. In 1960, DI benefits were extended to workers under the age of 50. In 1965, the definition of disability was expanded to include impairments expected to last at least a year, thus relaxing the requirement that disabilities must be of "long-continued and indefinite duration.” In 1973, DI beneficiaries became eligible for Medicare (the health insurance program for the elderly) after 24 months of disability. In 1984, Congress enacted reforms (detailed below) that substantially liberalized the disability screening progress, thus making disability benefits considerably more accessible to workers with non-life-threatening disorders such as mental illness and back pain. Cumulatively, these programmatic changes expanded the original narrow mandate of the DI program to encompass a broader population with a less precisely defined entitlement to benefits.

Adding to the complexity of an expanding program mission, five decades of advances in medical treatments and rehabilitative technologies, combined with a secular trend away from physically exertive work, have arguably blurred any sharp divide that may have once existed between those who are "totally and permanently disabled" and those who are disabled but retain some work capacity. While one might have expected these medical and labor market changes to reduce the incidence of disabling medical conditions and hence lower the relative size of the DI program, this has not occurred.

\section{The Application Process}

To apply for disability benefits, an individual must submit an application to a Social Security Administration field office, of which there are currently approximately 1,400 nationwide. Employees at the field office first check nonmedical criteria. Only adults below the full retirement age — which was 65 for individuals born in 1937 or earlier, and then phased up over time to 67 for those born in 1960 or later—are eligible for Disability Insurance. The applicant 
must have worked in at least five of the ten most recent years and cannot currently be engaging in a substantial gainful activity (no more than $\$ 860$ in monthly earnings in 2006). In an average year during the 1990s, approximately 10 percent of applications were denied for nonmedical reasons.

If the applicant meets the nonmedical criteria, the application is forwarded to one of the Disability Determination Services offices (Social Security Administration, 2004). These offices are administered by state governments, but act as agents of the Social Security Administration (House Ways and Means Committee, 1994). At this office, disability examiners and medical staff scrutinize medical evidence from one or more of the applicant's health care providers regarding the applicant's ability to perform work-related activities. If this medical information is insufficient, the office will commission and pay for an outside consultative medical examination of the applicant. If the Disability Determination Services office finds that the applicant has an impairment that meets or exceeds one of those on the official Listing of Impairments, then a disability award is made. If not, the next step is to consider the applicant's ability to work, taking into account health status, age, education, work experience and the transferability of the applicant's skills. If the office reaches a conclusion that the applicant cannot work, a disability award is made. In a typical year during the 1990s, approximately 37 percent of applicants were awarded benefits at this first stage.

If the original Disability Insurance application is denied, an applicant can pursue three levels of appeals, in this order: 1 ) request a reconsideration by a different team at the state office of Disability Determination Services; 2) request a hearing with an Administrative Law Judge; 3) appeal to the Social Security's Appeals Council, to the U.S. District Court and finally to the U.S. Circuit Court of Appeals. Of those initially denied benefits in recent years at the first stage of the 
application process, approximately 58 percent filed at least one appeal. More than half of those who appealed were eventually awarded disability benefits.

\section{The Generosity and Duration of Disability Insurance Benefits}

The level of disability benefits received is determined by a formula that starts by calculating average indexed monthly earnings (AIME), using the earnings data that is collected for calculating Social Security benefits. Past wages are indexed up to the present using an "inflator" equal to average wage growth in the economy. ${ }^{4}$ Years with the lowest earnings are excluded from the average, with five years after the age of 21 excluded for all awardees ages 43 and up and fewer years excluded for younger recipients. For very low-wage workers, disability benefits are equal to 90 percent of average indexed monthly earnings. As average indexed monthly earnings rise, the proportion of income replaced declines, so that low-wage workers replace a larger fraction of their earnings than do high-wage workers. ${ }^{5}$ The average monthly benefit for newly disabled workers in 2005 was $\$ 970$, and close to $\$ 1,100$ when accounting for dependent

\footnotetext{
${ }^{4}$ Nominal earnings in year $t$ for a person applying in year $T$ are multiplied by the ratio of average wages in year $T-2$ to average wages in year $t$, if $t=T-2$ or earlier. Indexed earnings equal nominal earnings in year $T-2$. Indexed earnings are set equal to nominal earnings for years $T-1$, and $T$.

${ }^{5}$ Specifically, an individual who becomes disabled at age $A$ years qualifies for DI average indexed monthly earnings (AIME) defined as:$$
\text { AIME }=\left(\frac{1}{A-25}\right) * \sum_{a=21}^{A} Y_{a} * \operatorname{Max}\left(1, \frac{\bar{Y}_{A-2}}{\bar{Y}_{a}}\right) * I_{a} .
$$

In this equation, $Y_{a}$ equals the person's average monthly earnings that were subject to Social Security taxes at age $a$ and $\bar{Y}_{a}$ equals average economy-wide earnings in that same year. Years with low earnings are excluded from this calculation, as explained in the text. The indicator variable $I_{a}$ is equal to one if indexed earnings at age $a$ are included in this calculation and zero otherwise. The monthly DI benefit is computed from the AIME using the following formula:

$$
P I A=\left\{\begin{array}{lll}
0.9 * A I M E & \text { if } & \text { AIME } \in[0, b 1] \\
0.9 * b_{1}+0.32 *\left(A I M E-b_{1}\right) & \text { if } & \text { AIME } \in(b 1, b 2], \\
0.9 * b_{1}+0.32 *\left(b_{2}-b_{1}\right)+0.15 *\left(A I M E-b_{2}\right) & \text { if } & \text { AIME > b2 }
\end{array}\right.
$$
}

where the bend points $b_{1}$ and $b_{2}$ are scaled each year by average nominal wage growth in the economy. 
benefits. As noted above, two years after the onset of their disability, recipients of Disability Insurance benefits also receive health insurance coverage through the federal Medicare program.

Once a person is enrolled in Disability Insurance, there are three main pathways out of the program. First, the DI recipient may reach the full retirement age, at which point the claimant shifts to the retired worker portion of Social Security. In 2004, more than 44 percent of those who left DI did so for this reason. Second, the claimant may die, which accounted for 42 percent of all program exits in 2004. Third, the claimant may no longer meet the nonmedical or medical standards for receiving disability benefits. For example, an individual may return to work and earn more than the permitted minimum amount, or the Social Security Administration may conduct a Continuing Disability Review and determine that the individual is no longer disabled. During the 2004 calendar year, eligibility-based exits accounted for 12 percent of all exits from the DI program.

In 1985, the Disability Insurance exit rate stood at 12.1 percent—-that is, one in eight claimants left the rolls. It has trended downward steadily since that time, reaching a low of 7.2 percent in 2004, an exit rate of just one in fourteen claimants. As shown in Figure 2, this decline has been driven both by a drop in the fraction of DI recipients reaching the full retirement age (from 6.7 to 3.3 percent) and in the fraction dying during the year (from 4.9 to 3.1 percent).

\section{Why Are the Disability Rolls Growing?}

By far the most important contributor to the recent growth of Disability Insurance is the liberalization of the DI screening process in 1984, which increased the number of disability awards and shifted the composition of recipients towards claimants with lower mortality disorders. Two other substantial contributors are rising financial incentives to apply for a 
disability award and changes in labor force participation that increase the share of citizens insured by, and therefore eligible to receive, DI benefits. By contrast, changes in health and age structure do not appear to be quantitatively important contributors. We discuss these factors in turn.

\section{Changes in Disability Screening}

The Disability Insurance program first paid out benefits in 1957, with 150,000 disabled workers enrolled in December of that year. By the end of 1977, 2.8 million nonelderly adults (2.8 percent of the nonelderly adult population) received disabled worker benefits from the DI program and an additional 2.0 million spouses and children received dependent benefits. The unexpectedly rapid increase in DI enrollment during the 1970s led to a funding crisis, with expenditures exceeding revenues by 25 percent in 1977 and the (inflation-adjusted) balance in the DI trust fund declining by more than 65 percent from 1974 to 1977 . As a result, the stateadministered Disability Determination Services offices were instructed to tighten the medical eligibility criteria for the program. Initial denial rates increased by 15.5 percentage points (30 percent) during the next three years (Gruber and Kubik, 1997). The medical eligibility criteria were tightened further by 1980 federal legislation that substantially increased the number of continuing disability reviews and made it more difficult for applicants to qualify for benefits. Between 1980 and 1983, the Social Security Administration determined that more than 380,000 beneficiaries of DI—40 percent of those whose cases were reviewed — no longer met medical standards and terminated their benefits (Rupp and Scott, 1998).

These actions yielded a significant decline in applications, awards and enrollment from 1980 to 1983 — and also generated a public backlash. Congress responded with legislation in 
1984 that made changes in two broad areas, profoundly altering the medical eligibility criteria for the Disability Insurance program and changing the evidentiary rules for continuing disability reviews. Prior to 1984, the disability determination process had focused on whether an applicant's objectively verifiable diagnostic criteria met or exceeded a listed impairment. The 1984 legislation enlarged this focus to consider an applicant's “ability to function in a work-like setting.” Under this law, the Social Security Administration was to place significant weight on applicants' reported pain and discomfort, to relax its strict screening of mental illness and to consider multiple nonsevere ailments ("impairments") as constituting a disability during the initial determination decision, even if none of these impairments was by itself disabling. Though these reforms did not alter the statutory definition of disability, they shifted the focus of screening from medical to functional criteria, which had a major effect on decision making. In the early years of the DI program, 93 percent of initial awards were based strictly on medical factors. In the year prior to the 1984 reforms, this number was 82 percent. Seventeen years later, the share of initial awards based strictly on medical factors had plunged to 58 percent (Social Security Advisory Board (Social Security Advisory Board, 2003).

The second major component of the 1984 legal reform made evidentiary rules for determining disability status more favorable to claimants. Historically, the Social Security Administration had placed greatest weight on its own consultative medical examination. The 1984 regulations required that evidence provided by the applicant's own health care provider have "controlling” weight, provided this evidence was not at odds with other medical evidence. These changes gave far more scope for appeal, with a resulting further decline in the share of awards due to strictly medical factors. While 58 percent of initial awards in 2000 were based on strictly medical factors, by the end of the appeals process, the share of all awards due to purely 
medical factors was only 40 percent (Social Security Advisory Board, 2003).

The reform of Disability Insurance in the 1980s ushered in two decades of program expansion. In the 21 years following the 1984 legislation, the DI rolls grew by 148 percent, from 2.6 million to 6.5 million beneficiaries, and the percentage of the nonelderly adult population receiving disability benefits from the program grew from 2.2 to 4.1 percent. For comparison, the number of workers insured by Disability Insurance grew by 38 percent and the nonelderly U.S. adult population ages 25 to 64 grew by 33 percent.

Accompanying this numerical growth was a major shift in the composition of the Disability Insurance beneficiary population. Table 1 shows that just four categories of diagnoses (“impairments”) make up approximately 70 percent of all disability awards: heart disease (more generally, circulatory disorders); cancers; mental impairments; and musculoskeletal disorders (typically back pain or arthritis). Since 1983, the relative importance of these categories has changed dramatically. Reflecting the increased weight given to pain and workplace function, the number of new DI awardees with a primary diagnosis of musculoskeletal disease or mental disorder - the two disorders with the lowest mortality among the 14 major diagnostic categories (Hennessey and Dykacz, 1993)—increased by 323 percent between 1983 and 2003 and accounted for more than half of all disability awards in the latter year. The corresponding increases in cancers and heart disease awards together were 30 percent, and thus lower than the increase in the insured population during that period.

Because mental and musculoskeletal disorders have an early onset and low age-specific mortality, Disability Insurance beneficiaries with these diagnoses experience relatively long durations on the program. Thus, in 1983, 4.9 percent of people receiving disability insurance in that year died; by 2004, only 3.1 percent of those receiving disability benefits in that year died. 
Reflecting the younger age of entry into DI, the fraction exiting the program for retirement declined from 7.0 percent in 1983 to just 3.3 percent by 2004, as shown in Figure 2. By implication, the average duration of receipt of disability benefits among new beneficiaries has lengthened substantially as the share leaving the program due to death or retirement has diminished.

\section{The Rising Value of Disability Insurance Benefits}

The value of Disability Insurance benefits relative to potential labor market earningsthe "replacement rate"-has risen substantially since the late 1970s (Autor and Duggan, 2003). This rise is not the result of direct legislative intention, but rather has occurred because of an interaction between the disability benefits formula and the growth of earnings inequality in the U.S. economy (Katz and Autor, 1999). Although DI benefits awarded are nominally only a function of a worker's prior earnings, award amounts are calculated using a wage index equal to mean wage growth economy-wide. Consequently, an individual's benefit also depends implicitly upon the individual's earnings growth relative to the growth of earnings for all workers during that worker's years of employment.

Figure 3 illustrates how this indexation scheme interacts with earnings inequality to raise the replacement rate of low-earnings workers. Line segment A-B-C depicts the benefits schedule of a worker awarded Disability Insurance benefits in 1980 whose wage growth prior to receiving DI exactly paced mean earnings in the economy. The worker's calculated average indexed monthly earnings amount (AIME) is identical to her 1980 wage. Because the benefits formula replaces between 15 and 90 percent of the marginal dollar (depending on the claimant's AIME), her monthly payment Primary Insurance Amount (PIA) falls somewhat below her 1980 wage. 
Next, consider a worker, represented by line segment A-B-D-E, who is awarded Disability Insurance benefits in 2000. This worker's nominal wage history in 2000 is identical to that of the beneficiary in 1980 but, in contrast to the 1980 beneficiary, his wage growth during his career lagged contemporaneous average wage growth economy-wide. This worker will receive a higher real Primary Insurance Amount than the worker entering Disability in 1980. Why? The indexation of the earnings "brackets"-that is, the ranges over which income is replaced at the 90, 32 or 15 percent rates-moves these brackets upward, causing a larger share of the worker's income to be replaced at the 90 or 32 percent rates than would have been the case in 1980. We label this as the "bracket effect” in Figure 3. Indexation also raises this worker's DI benefit through a second channel. Because the more recent worker's entire earnings history is inflated by historical mean wage growth, his average indexed monthly earnings amount will actually exceed current earnings (recall that his wage growth has lagged the economy-wide average). We label this as the "earnings history effect” in Figure 3. Jointly, these two forcesindexation of the earnings brackets and indexation of past earnings—-have substantially raised the income replacement rate of low-earnings DI beneficiaries since 1979, when earnings inequality began growing rapidly.

Augmenting the increase in the replacement rate for Disability Insurance benefits is a substantial rise in the real value of the Medicare entitlement received by disabled persons. Average Medicare expenditures per recipient of DI more than doubled from \$3,259 in 1979 to \$7,700 in 2005 (both in 2005 dollars). ${ }^{6}$ Simultaneously, private sector health insurance coverage rates fell steeply, particularly for low-earnings workers (Farber and Levy, 2000), thus further increasing the relative value of the Medicare benefit.

\footnotetext{
${ }^{6}$ Bhattacharya and Schoenbaum (2002) estimated the present value of the Medicare benefit to new Disability Insurance recipients at $\$ 40,000$ for males and $\$ 50,000$ for females, with a value as high as $\$ 75,000$ for recipients with a diagnosis of mental illness.
} 
Table 2 shows the effects of these factors on Disability Insurance replacement rates for currently employed male workers ages 30 to 61 at various percentiles of the age-specific earnings distribution in 1984 to 2002. The first pair of columns shows the earnings replacement rate for different groups of retirees. The second pair of columns shows replacement rates with the value of Medicare benefits taken into account, while netting out average fringe benefits earned on the job. For example, in 1984, currently employed male workers ages 50 to 61 at the tenth percentile of the earnings distribution could potentially have replaced 55 percent of their current earnings with DI cash transfers. By 2002, this share had risen to 64 percent. Accounting for the rising value of in-kind Medicare benefits and netting out average fringe benefits earned on the job in the final column, the overall disability-related replacement rate for a tenth percentile male age 50 to 61 rose still further from 68 to 86 percent.

Nor was this rise limited to older workers. For males at or below the median earnings level, the rise in the replacement rate inclusive of Medicare ranged from 9 to 25 percentage points across all age brackets. The rise in the replacement rate was far less pronounced at higher positions in the earnings distribution, as one would expect from the way in which benefits are calculated. For workers at the $90^{\text {th }}$ percentile of earnings, potential replacement rates rose a comparatively modest 1 to 2 percentage points.

The rising Disability Insurance replacement rate probably spurred additional DI applications and awards. While it is difficult to distinguish the effects of changes in program rules versus changes in generosity of program benefits, the replacement rate increase was particularly pronounced for low-earnings workers, the group who saw their real market wages fall sharply during the 1980s. This pattern suggests that DI should have become more attractive to the less-skilled and less-educated over this period. We examined this implication using data 
from the Survey of Income and Program Participation (SIPP), and some of the results are shown in Table 3.

The increase in DI enrollment during the last two decades was largest for those without a high school degree, with especially large increases for those between the ages of 40 and 64. In 2004, high school dropout males ages 40 through 64 were five times as likely as males with a college degree and twice as likely as males with only a high school degree to receive DI benefits.

\section{The Roles of Aging and Labor Supply}

The aging of the U.S. population —in particular, the passing of the baby boom generation into middle age — has so far made only a modest contribution to the growth of Disability Insurance. Calculations from Duggan and Imberman (forthcoming in 2006) that have been updated for this article reveal that, holding age-specific rates of receipt of disability benefits at their 1984 base, the aging of the population between 1984 and 2004 explains only 6 percent of the increase in the fraction of nonelderly adults receiving Disability Insurance.

Why is this contribution so small? First, the baby boom cohorts have yet to reach their peak disability years. Disability rises rapidly starting around age 50. In 1984, a male age 60 to 64 was 5.7 times more likely to receive Disability Insurance than a male age 40 to 44 and 1.9 times more likely than a male age 50 to 54 (based on data from the Social Security Administration Annual Statistical Supplement, 1985, 2005). However, between 1980 and 2000, the share of the population that was near-elderly, ages 50 to 64 , was nearly constant at 15 percent of the population.

A second reason that aging does not appear more important is that its contribution is numerically overwhelmed by the growth of Disability Insurance receipt within given age groups. For example, if one divides males between 25 and 64 into five-year age groups, DI receipt 
increased within each group by an average of 41 percent. This increase was especially sharp for males ages 40 to 49, for whom the rate receipt rose by 65 percent. Ironically, the only male age group for which disability receipt did not increase by more than 20 percent during this period is those ages 60 to 64 .

The growth of disability receipt between 1984 and 2004 was far more pronounced among women than men. Whereas male disability receipt grew by 41 percent, female receipt grew by 151 percent, thus raising the ratio of female to male recipients from five females for every ten males in 1984 to eight females for every ten males in 2004. A significant—-though far from complete-explanation for this fact is the secular rise in female labor supply in recent decades, which has been particularly rapid since 1970 (Blau, Ferber and Winkler, 2002). Between 1984 and 2004, the share of women ages 25 to 64 eligible to receive Disability Insurance benefitsthat is, having worked in a job covered by Social Security in at least five of the ten most recent years-grew by 25 percent, from 61 to 76 percentage points. Holding rates of receipt of DI constant among workers at its 1984 level, the increased number of women in the paid labor force can explain only about one-sixth of the 151 percent increase in the rate of DI receipt among women. By contrast, the fraction of nonelderly men covered by DI has remained virtually unchanged in this period (at roughly 90 percent) and so has not been a major contributor to the increase in their receipt of disability benefits.

\section{The Role of Health}

A final potentially important demographic factor affecting the receipt of Disability Insurance is health. One straightforward and commonly used measure of the health status of a group is mortality. Between 1981 and 2001, annual mortality rates for men and women between the ages of 50 and 64 fell by 29 and 17 percent respectively, according to data from the Social 
Security Administration available online at <http://www.demog.berkeley.edu/ bmd/states.html > Annual mortality rates for men in their 40s declined by approximately 18 percent during this period and for women in this same age group by 24 percent. Perhaps other adverse health trends, like obesity, may have diminished the ability of working age adults to participate in the labor market. Duggan and Imberman (forthcoming in 2006) explore this issue using measures of selfreported health status from the National Health Interview Survey, focusing on the prevalence of activity or work-limiting conditions. Their findings for adults between the ages of 50 and $64-\mathrm{a}$ group that accounted for 62 percent of all DI recipients in 2004—reveal a substantial improvement in their average health since 1984. Reinforcing these conclusions, Manton and Gu (2001) find that the share of the population age 65 and over suffering from a chronic disability fell from 26.2 in 1982 to 19.7 percent in 1999—a decline of 33 percent—with the largest drop between 1994 and 1999 (see also U.S. Census Bureau, 2005, chapter 3).

In summary, we conclude that changes to the Disability Insurance program itself-the liberalization of screening and the rise in the replacement rate—and their interactions with the labor market are the central factors explaining the outsized growth of Disability Insurance receipt since 1984. Aging and health are comparatively minor factors.

\section{What Share of Disability Recipients are Undeserving?}

\section{The Work Capability of Disability Insurance Recipients}

In the last two decades, the average health of the U.S. population has been improving while the share of working-age adults receiving disability benefits has been increasing. Judged by historical standards, are all of the new recipients “deserving” of a lifetime of income and 
medical care paid for by the Social Security Administration and the Centers for Medicare and Medicaid Services? Put more bluntly, are a substantial share of Disability Insurance recipients cheating? This cheating could take different forms: Work-capable individuals, including those with nondisabling impairments, might exit the labor force to claim benefits. Alternatively, individuals who are voluntarily or involuntarily out of the labor force but not impaired might file a disability claim to gain income support and health insurance. ${ }^{7}$

The extent of such cheating is difficult to evaluate for both practical and policy reasons. At a practical level, there are no systematic, objective data on the work capacity of current Disability Insurance beneficiaries and so there is no reliable means to estimate what share could potentially work. Nor can the question of cheating be resolved by an appeal to medical standards. While certain medical conditions are clearly disabling, "disability” is not a medical condition. Disability is a dividing line (or zone) chosen by policymakers on a continuum of ailments affecting claimants' capability to engage in paying work and their pain and discomfort in doing so (Diamond and Sheshinksi, 1995). Beyond the subset of clearly incapacitating medical and mental disorders, the extent of "disability" is ultimately a variable determined by policy.

One approach to evaluating to what extent Disability Insurance leads work-capable individuals to seek benefits in lieu of working is to ask what share of DI applicants would be working in the absence of the program. Commencing with a 1989 paper by John Bound, a series of studies has attempted to evaluate the work capability of DI applicants by comparing the labor supply, later in life, of those accepted and rejected for disability benefits. In these studies, the

\footnotetext{
${ }^{7}$ In evaluating the first type of moral hazard wherein workers leave the labor force to claim benefits, one should ideally distinguish between distortionary and nondistortionary components of moral hazard. Disability Insurance provides a large permanent income boost in the case of an adverse medical shock, and this may reduce labor supply purely through an income effect—a nondistortionary effect. Alternatively, the program may cause workers to reduce labor supply to appear more disabled and therefore qualify for DI benefits. This is a distortionary (substitution) effect. We know of no existing research on disability that attempts to distinguish these effects (except for work in progress by the authors, Autor and Duggan, 2006).
} 
fraction of applicants for DI who return to work after their applications is taken as an estimate of the work capacity of rejected disability applicants, who in turn are presumably more workcapable than accepted applicants.

This methodology, while ingenious, has important limitations. First, it may be biased towards underestimating the labor supply disincentives of the Disability Insurance system (Parsons 1980, 1991; Bound, 1991). Some rejected applicants may remain out of the labor force because they are reapplying for DI while other rejected applicants may be unable to find reemployment because their skills and opportunities deteriorated during the application process. Second, this approach is unable to detect the form of cheating identified above in which individuals who are not disabled and not labor force participants—perhaps because they lack marketable skills—file false claims. These individuals would not be expected to work even absent a disability award.

Bound's original study, using data from the 1970s, concluded that at most 30 percent of rejected male applicants for Disability Insurance over the age of 45 would have worked if it were not for the availability of DI benefits. Given the considerable expansion in DI enrollments since 1984, one might expect the fraction of rejected applicants who are work-capable to have risen since Bound's analysis. Surprisingly, Chen and Van Der Klauuw (2005) find that for males over age 45 applying for DI benefits during the 1990s, labor supply would only have been 30 to 40 percent higher were it not for the availability of the program—a figure that is comparable to both Bound's earlier estimates and to estimates by Bound, Burkhauser and Nichols (2001).

The fact that rejected Disability Insurance applicants are not substantially more likely to return to work in the 1990s than they were in the 1970s suggests one of two explanations. Either rejected applicants are not more work-capable than in past years or, alternatively, labor market 
conditions for those most likely to apply for disability benefits—primarily low-skilled workers— have deteriorated sufficiently that even applicants who would have been work-capable several decades ago are now unlikely to find employment (Chen and van der Klauuw, 2005; Juhn, Murphy and Topel, 2002). Consistent with this latter view, Autor and Duggan (2003) demonstrate that the responsiveness of DI applications to adverse labor market shocks rose sharply between 1984 and 1998, particularly for less-educated workers. This pattern suggests that a growing fraction of discouraged and displaced workers are seeking disability benefits. ${ }^{8}$

\section{Is the Screening Process Broken?}

Some abuse of a large public insurance system like the Disability Insurance program is inevitable. But has such abuse reached unsustainable levels so that the DI screening process is effectively broken? In our assessment, the answer is yes. At an operational level, the Social Security Administration has become progressively less effective at rejecting claims that fail to meet its selection criteria. At a more fundamental level, the definition of disability that Congress adopted in 1984 (and has since expanded) is so encompassing that the DI program appears in practice to function like a nonemployability insurance program for a subset of beneficiaries, rather than (primarily) as an insurance program for medical impairment. We consider these failings in turn.

The 1984 liberalization of Disability Insurance vastly increased the complexity and subjectivity of disability screening (Social Security Advisory Board, 2001). Prior to 1984 (as discussed earlier), determinations of disability focused primarily on medical criteria and gave limited credence to nonverifiable symptoms such as pain and mental disorders. The revamped

\footnotetext{
${ }^{8}$ For further discussion of the impact of the Disability Insurance program on labor supply, see Bound and Waidmann (1992), Bound and Burkhauser (1999), Burkhauser and Daly (2002), Autor and Duggan (2003) and Stapleton and Burkhauser (2003).
} 
process is much more subjective, requiring the Social Security Administration to evaluate an applicant's workplace function and the extent of pain or mental illness, to determine the veracity of supporting evidence provided by the claimant, and to give primary weight to that evidence unless it is at odds with other information.

Despite repeated efforts by the Social Security Administration to improve the efficiency, accuracy and consistency of disability screening (United States General Accounting Office, 1997; 2003), the disability determination process appears to be evolving from a bureaucratic function to an adversarial process relying heavily on appeals and adjudication. In 1986, about half (54 percent) of all applications for disability who were denied at the initial appeal stage by their state-level Disability Determination Services Office were subsequently appealed to Administrative Law Judges. Eleven years later, 83 percent of all reconsideration denials were appealed in this next step (U.S. GAO, 1997). The Social Security Administration (SSA) adjudication system is now thought to be the largest system of trial-type adjudication in the world (Verkuil and Lubbers, 2002), employing at present 980 full-time judges. Of all appeals filed in 2005, 92 percent were for disability cases and only 8 percent of appeals were for retirement or Medicare cases (SSA Annual Statistical Supplement, 2005).

The sophistication of claimant appeals has risen demonstrably. Between 1977 and 2000, the share of disability claimants represented by an attorney at the Administrative Law Judge hearing nearly doubled from 37 to 70 percent (Social Security Advisory Board, 2001). The share of claimants represented by a medical or vocational expert also increased sharply, more than quadrupling between 1984 and 2000, from 15 percent to 65 percent. Claimants represented by an attorney prevail three times as often at trial as unrepresented claimants (U. S. GAO, 2003). This relationship may not be entirely causal—claimants with stronger cases may find it easier to 
obtain representation—but it appears unlikely to be entirely spurious. ${ }^{9}$ Disability litigation practice has matured as a viable business model, with hundreds of law firms now pursuing this specialty. In 1997, the most recent year for which figures were available, the Social Security Administration paid nearly half a billion dollars to claimants’ attorneys (Social Security Advisory Board, 1998).

Decisions about what constitutes a legitimate disability claim are gradually being taken from the Social Security Administration. In 1979, approximately one in eight Disability Insurance awards (12 percent) was granted by an Administrative Law Judge. By 2002, this share had more than doubled to 27 percent (House Ways and Means Committee, 1998, 2004). Nor does the appeal process necessarily stop at the Administrative Law Judge. In fiscal year 2000, 98 percent of applicants whose claims were denied by an Administrative Law Judge appealed their claim to the Social Security Administration Appeals Council, which allowed 2 percent of claims and remanded another 22 percent back to the judge (60 percent of which will likely be awarded on remand). Of those denied by the Appeals Council, 13 percent appealed to the federal civil courts. Between 1990 and 2000, the number of disability cases filed in federal courts nearly tripled from approximately 5,000 to 15,000, representing 5.9 percent of all civil cases in the Court of Appeals in 2000 (Verkuil and Lubbers, 2002, p. 9). Accounting for all levels of appeal, more than 38 percent of awards to individuals who applied for Disability Insurance between 1997 and 2000 were made after an initial denial, versus just 20 percent between 1975 and 1977

\footnotetext{
${ }^{9}$ Lawyers in this specialty have strong financial incentives to prolong disability cases until they reach the appeals phase. Following a successful disability appeal, the Social Security Administration grants 25 percent of the retroactive disability award to the claimant's attorney (currently capped at $\$ 5,300$ ). Because the size of the retroactive benefit — and hence the attorney's fee-increases with the duration of the appeal, it is widely believed that claimant attorneys withhold key evidence (such as medical records) until the case reaches appeals (U. S. GAO, 1997; Verkuil and Lubbers, 2002). The U. S. General Accounting Office (1997) reports that in 1997, 76 percent of appealed cases contained new evidence. The introduction of new evidence late in the appeal is permissible because of an unusual feature of the Social Security Administration appeals process: the evidentiary record is not closed prior to the appeal to the federal court.
} 
(Lando, Farely and Brown 1982).

Perhaps such a transformation of the screening process was inevitable given the litigiousness of American society and the large awards at stake. It seems unlikely, however, that the problem would be as severe were it not for the 1984 reforms. Whatever the reason, the increase in the fraction of DI awards made on appeal raises the concern that the Social Security Administration is gradually losing control of the decision-making process on eligibility for disability benefits.

\section{Disability Insurance or Unemployability Insurance?}

Disability Insurance applications typically rise and fall with the unemployment rate, as shown in Figure 4 (Rupp and Scott, 1998; Black, Daniel and Sanders, 2002; Autor and Duggan, 2003). (The one exception to this pattern, seen during 1980 to 1984, occurred when the retrenchment of DI from 1980 to 1984 reduced disability applications while the U.S. unemployment rate soared.) Since it seems unlikely that the onset of disability is countercyclical, this pattern could be taken as prima facie evidence that the DI system is being abused as a form of unemployment insurance. But from a legal standpoint, this inference is incorrect. The original, statutory definition of a disability — “the inability to engage in a substantial gainful activity in the U.S. economy"-depends explicitly on an applicant's job opportunities. As Congress has broadened the scope of the disability program over five decades to encompass workers of all ages, to cover medium-term (lasting at least one year) as well as permanent disabilities, and to place substantial weight on both functional and medical criteria, this focus on labor market criteria has become paramount.

Four of the five steps in Social Security's current evaluation process ask whether the Disability Insurance applicant is currently working, can perform basic work tasks, could return to 
her past work or could be retrained for other work in the national economy. By contrast, only one of the five steps concerns whether the applicant's impairment meets the Social Security Administration's (SSA's) medical criteria. If this level of medical severity is not met, however, the claim may still be awarded if the SSA determines that the applicant is unable to perform her past work and unable to be retrained for new work (as explained at $<$ http://www.ssa.gov/dibplan/dqualify5.htm>). These criteria ensure that adverse economic shocks will spur those with relatively poor health and limited labor market opportunities to seek and qualify for disability benefits.

To give one illustrative example of the degree to which Disability Insurance has moved from its original role of insuring workers against physical incapacity to one of insuring workers against nonemployability, consider what occurred following passage of a 1996 law disqualifying Disability Insurance claimants whose primary impairment was drug or alcohol addiction. The Social Security Administration soon terminated approximately 130,000 beneficiaries (note the spike in Medical Disqualifications in 1997 in Figure 2). Remarkably, two-thirds of these terminated claimants eventually re-qualified for DI benefits under a different impairment (Lewin Group, 1998). Beyond highlighting the inability of the Social Security Administration to deflect aggressive claimants, this example points to a structural problem. Because the legislative definition of disability turns primarily on a claimants' nonemployability, it is ultimately unsurprising that the majority of terminated beneficiaries would requalify for benefits under a different impairment.

\section{Implications for Future Enrollment and Finances}




\section{How Much Further Will Disability Insurance Enrollment Increase?}

In the 1980s and 1990s, the rising number of recipients of Disability Insurance has largely been driven by a steady increase in the award rate per insured population. But in recent years and into the future, the predominant cause of the current and projected future increase in enrollment is the decline in the exit rate from the program. As shown earlier in Figure 2, the fraction of DI recipients leaving the program in each year has consistently fallen. In 1983, 16.4 percent of those receiving disability benefits in that year exited the program because of death, entering retirement, or no longer meeting the criteria for disability. By 2005, only 7.2 percent of those receiving disability benefits in that year exited the program.

If one approximates the average duration of time spent receiving disability benefits as equal to the reciprocal of the exit rate, the mean duration of disability benefits has increased from six years in 1983 to 14 years in 2004. Assuming that this duration remains constant and that the DI award rate remains at approximately 0.5 percent per year (the average from 2002 to 2004), in the future the DI program will ultimately level out when it pays benefits to 7 percent of the nonelderly adult population. This would represent a 71 percent increase above the 4.1 percent rate of DI enrollment at the end of 2005.

For comparison, the Board of Trustees of the Social Security Administration (2005) makes an “intermediate” projection that Disability Insurance enrollment will increase from 6.2 million in 2004 to 9.8 million by 2025. However, this projection assumes a rapid slowdown in the growth of the program. For example, after increasing by 5.3 percent per year from 2000 to 2004, the trustees assume that the disability rolls will only increase at 3.5 percent per year from 2004 to 2010 and at 1.6 percent per year from 2010 to 2020 . While the trustees’ projections may prove accurate, their previous estimates have tended to be too low. The 2001 Trustee’s report predicted an increase in DI enrollment from 5.0 million in 2000 to 6.1 million in 2005. The 
actual increase during this five-year period was 36 percent higher.

\section{Implications for Social Security and Medicare Finances}

The Social Security program paid out $\$ 521$ billion in cash benefits to approximately 48.4 million individuals during the 2005 calendar year from two separate trust funds: the Old Age and Survivors Insurance (OASI) Trust Fund and the Disability Insurance Trust Fund. Each trust fund has three main sources of revenue: payroll taxes, interest on the accumulated assets in the trust fund, and income from the taxation of Social Security benefits. Payroll taxes are by far the most important, accounting for more than 84 percent of the $\$ 702$ billion in program revenues during the 2005 calendar year. Since 1990, workers covered by Social Security have paid a flat 12.4 percent tax on earnings in each year up to a taxable maximum. This taxable maximum, indexed to average economy-wide wage growth, was equal to $\$ 90,000$ in 2005 . While the Social Security tax rate has remained unchanged since 1990, the share going to DI has risen. In 1990 the tax rates for the DI and OASI trust funds were 1.2 and 11.2 percent, respectively, but they are currently set to 1.8 and 10.6 percent.

Spending on Disability Insurance accounted for 10.1 percent of Social Security spending in 1990, but rose to 16.6 percent in 2005. Absent major changes to the Disability Insurance program, the current tax rate of 1.8 percent will not suffice to finance disability benefits, meaning that a larger share of the Social Security tax will be unavailable for financing retirement benefits. ${ }^{10}$

Trends in Disability Insurance enrollment have important implications for Medicare

\footnotetext{
${ }^{10}$ The Social Security trust funds continue to pay benefits to Disability Insurance recipients once they reach the full retirement age and are shifted from the Disability Insurance to the Old Age and Survivors Insurance rolls. During the 2002 calendar year, approximately one out of every eight retired worker awards went to 65-year-olds who had been receiving Disability Insurance. If one accounts for these Old Age and Survivors Insurance expenditures, the fraction of Social Security payments given to past or current Disability Insurance recipients is much greater than the 16.6 percent share noted above.
} 
financing as well. During the 2005 calendar year, DI recipients accounted for 15.4 percent of all Medicare recipients and 15.1 percent of the $\$ 325$ billion in Medicare expenditures (United States Department of Health and Human Services, 2005). The share of Medicare spending accounted for by DI recipients has also increased.

\section{How Should Disability Insurance be Reformed?}

The rapid growth of Disability Insurance enrollment during the past two decades appears poised to continue and even to accelerate as the baby boom cohorts attain their peak disability years, reaching more than 6 percent of the nonelderly U.S. adult population in the next decade and accounting for more than 8 percent of the federal budget. The rapid growth of Disability Insurance does not appear to be explained by a true rise in the incidence of disabling illness, but rather by policies that increased the subjectivity and permeability of the disability screening process. A broadening societal definition of disability and increased willingness of individuals to seek government benefits may also have played some role, though we have no direct evidence on these points.

What might be done? There are three ways to reduce the size of the Disability Insurance program: shorten the average length of time that claimants receive benefits by encouraging faster exit; tighten the screening process so that fewer insured workers may qualify; and reduce the incentives for qualified workers to seek benefits. We discuss these options in turn.

Raising the exit rate from the Disability Insurance rolls has been tried in various ways, but has not worked well. As discussed earlier, an aggressive increase in Continuing Disability Reviews during 1980 through 1983 reduced the DI rolls by approximately 13 percent in three 
years. But the ensuing public backlash and a series of court reversals galvanized Congress's 1984 liberalization of the disability screening process and arguably led to the present day crisis; in fact, many of the beneficiaries terminated from 1980 to 1983 were later reinstated on appeal. Similarly, Congress' attempt to disqualify DI recipients whose primary impairment was drug or alcohol addiction did not ultimately remove the majority of these recipients from the rolls. In another example, Congress in 1999 enacted the Ticket-to-Work program, which extended Medicare benefits for up to eight years to DI beneficiaries who rejoined the workforce and provided beneficiaries with "tickets" to assign to their vocational providers, who would receive bonuses if the beneficiary returned to full-time work. However, only 8,900 of the more than 11.4 million tickets issued to date have been taken up by claimants and their providers, and fewer than 1,400 of these have led to successful workforce integration. ${ }^{11}$ These experiences suggest that once awarded, disability benefits are extremely difficult to rescind.

A more promising avenue for slowing program growth may be to reduce inflows to the Disability Insurance program. One method to stem inflows is to adopt more rigorous eligibility criteria that emphasize medical rather than vocational factors, as was done in the late 1970s and early 1980s. However, any reduction in the award rate for nonmeritorious claims would surely be accompanied by a rise in the rejection rate for deserving claimants suffering from difficult-toverify impairments, such as pain and mental disorders. Although we view this trade-off as potentially worthwhile, it is not clear that it would be politically sustainable.

Less controversial would be reforms that simultaneously raised the rejection rate of nonmeritorious claims while increasing the acceptance rate of deserving claims. Two policy reforms hold this potential. First, the Social Security Administration might be routinely allowed

\footnotetext{
${ }^{11}$ Statistics on Ticket to Work (accessed on 3/27/2006) are continually updated at http://www.socialsecurity.gov/work/Ticket/ticket_info.html\#TicketTracker.
} 
to commission independent medical and vocational evaluations of Disability Insurance claimants during the initial determination. This change would provide a healthy counterbalance to the current requirement that Disability Determination Services examiners give highest weight to source evidence submitted by claimants and their selected medical representatives, which seems to invite a highly skewed presentation of facts. ${ }^{12}$

A second promising step would be for the Social Security Administration to consider attorney representation at Administrative Law Judge hearings, as the independent Social Security Advisory Board (2001) has repeatedly recommended. At present, claimants are typically represented at appeal by legal and medical advocates who have a financial stake in the claimant's success. The Social Security Administration, by contrast, is entirely dependent on the Administrative Law Judge to protect the claimant's and the public's interests simultaneously (U.S. GAO, 1997). Permitting the Social Security Administration to provide a representative or attorney to the hearings would ameliorate this almost comically lopsided setting, in which the Social Security Administration currently loses nearly three-quarters of all appeals. ${ }^{13}$

An alternative means to stem Disability Insurance inflows is to lower the number of workers seeking benefits. Individuals with expensive-to-treat but not otherwise incapacitating disorders are likely to have difficulty in obtaining health insurance and hence will find the Medicare component of the DI system particularly attractive. In this way, DI may serve as a health insurer of last resort for otherwise work-capable individuals. Gruber and Kubik (2005)

\footnotetext{
${ }^{12}$ Benitez-Silva, Buchinsky and Rust (2004) propose improving Disability Screening through better statistical evaluation of claimant evidence. Golosov and Tsyvinski (2006) make a case for asset-testing of disability claimants to discourage undeserving applicants, who face an incentive to stockpile assets in anticipation of submitting a claim (given that they would no longer be working and disability benefits are lower than potential earnings.)

${ }^{13}$ The Social Security Administration reported to Congress in 1985 that a pilot study found that Administrative Law Judge awards made in error could be cut by half if the Social Security Administration was represented at appeal hearings (Hearing before the Select Committee on Aging, House of Representatives, $99^{\text {th }}$ Congress, $1^{\text {st }}$ session, Mar. 18, 1985). In 1986, however, a federal court ruled that representation for the Social Security Administration, at least as implemented in the pilot, violated procedural due process (U. S. GAO, 1997, p. 43).
} 
show that potential applicants for DI coverage who would lose other insurance coverage while awaiting eligibility for the disability-related Medicare benefit are substantially less likely to apply for disability than are potential beneficiaries who have stopgap forms of health coverage. For this reason, successful efforts to close the fissures in the U.S. health care system might have the additional benefit of reducing applications for Disability Insurance.

Finally, one radical reform to reduce the incentive to seek disability benefits is to scrap the current all-or-nothing cash award in favor of a graduated disability scale similar to that used by the Disability Compensation program in the Department of Veterans Affairs. Under this program, benefits awarded are an increasing function of the claimant's disability, rated on a scale from zero to 100 percent. Claimants with mild impairments receive smaller payments and therefore have weaker incentives to seek awards. Moreover, because benefit payments in the Disability Compensation program are not conditioned on staying out of the labor force, the system does not directly reward labor force nonparticipation.

Relative to the current Disability Insurance system, there are, however, two clear drawbacks to the Disability Compensation model. First, if the disabled could both work and collect benefits, the pool of workers seeking and obtaining disability benefits would surely increase. Second, the workforce nonparticipation requirement of the current DI program likely induces favorable self-screening; only the neediest applicants—-those with low earnings capacity and high disutility of work-are likely to apply. To date, researchers have largely neglected study of the Veteran's Disability Compensation program, though careful economic analysis of it is clearly warranted.

There are no easy reforms to Disability Insurance. The disabled are generally held in high regard by the public — unlike, for example, the standing of welfare recipients prior to passage of 
welfare reform in 1996. General Social Survey data from 1994 showed that 60 percent of the U.S. respondents believed that "we are spending too much on welfare" (Weaver, Shapiro and Jacobs, 1995). In the same year, a Kaiser poll found that 58 percent of Americans believed that the federal government should be spending "more" or "much more" on poor adults who are disabled (Center for Study of Policy Attitudes, University of Maryland, 1994). But with the present value of new DI awards and the accompanying Medicare coverage now exceeding \$200 billion per year, and rising, the cost of postponing reforms to DI may eventually come to appear even more daunting than the cost of facing them promptly. 


\section{References}

Autor, David H. and Mark G. Duggan. 2003. “The Rise in the Disability Rolls and the Decline in Unemployment.” Quarterly Journal of Economics.118:1, February, 157-206.

Autor, David H. and Mark G. Duggan. 2006. “The Pure Income Effect of Disability Cash Transfers: Evidence from the Veteran Administration's Disability Compensation Program.” Unpublished paper, Massachusetts Institute of Technology.

Autor, David H., Lawrence F. Katz and Melissa S. Kearney. 2005. “Trends in U.S. Wage Inequality: Re-Assessing the Revisionists.” NBER Working Paper No. 11627.

Benitez-Silva, Hugo, Moshe Buchinsky and John Rust. 2004. "How Large are the Classification Errors in the Social Security Disability Award Process?” NBER Working Paper No. 10219, January.

Bhattacharya, J. and Michael Schoenbaum. 2002. "The Value of the Medicare Benefit for Social Security Disability Insurance Recipients.” University of Michigan, Economic Research Initiative on the Uninsured Working Paper No. 10, July.

Black, Dan, Kermit Daniel and Seth Sanders. 2002. “The Impact of Economic Conditions on Participation in Disability Programs: Evidence from the Coal Boom and Bust.”American Economic Review. 92:1, 27-50.

Blau, Francine D., Marianne A. Ferber and Anne E. Winkler. 2002. The Economics of Women, Men, and Work. $4^{\text {th }}$ edition. Upper Saddle River, NJ: Prentice Hall.

Bound, John. 1989. "The Health and Earnings of Rejected Disability Insurance Applicants.” American Economic Review. 79:3, pp. 482-503.

Bound, John. 1991. "The Health and Earnings of Rejected Disability Insurance Applicants: Reply.” American Economic Review. December, 81:5, pp, 1427-34.

Bound, John and Richard Burkhauser. 1999. "Economic Analysis of Transfer Programs Targeted on People with Disabilities." Handbook of Labor Economics. Vol. 3. Orley Ashenfelter and David Card, eds. Amsterdam: North-Holland.

Bound, John, Richard Burkhauser and Austin Nichols. 2001. "Tracking the Household Income of SSDI and SSI Applicants.” University of Michigan Retirement Research Center Working Paper No. 2001-009.

Bound, John and Timothy Waidmann. 1992. "Disability Transfers, Self-Reported Health and the Labor Force Attachment of Older Men: Evidence from the Historical Record." Quarterly Journal of Economics. 107:4, pp, 1393-1419.

Burkhauser, Richard and Mary Daly. 2002. "Policy Watch: U.S. Disability Policy in a Changing Environment.” Journal of Economic Perspectives. Winter, 16:2, pp. 213-24. 
Center for Study of Policy Attitudes, University of Maryland. 1994. Poll of 10/13/1994.

Chen, Susan and Wilbert van der Klauuw. 2005. "The Work Disincentive Effects of the Disability Insurance Program in the 1990s.” Unpublished paper, University of North Carolina, Chapel Hill, September.

Diamond, Peter and Eytan Sheshinski. 1995. "Economic Aspects of Optimal Disability Benefits.” Journal of Public Economics. 57:1, pp, 1-23.

Duggan, Mark and Scott Imberman. Forthcoming (2006). "Why Are the Disability Rolls Skyrocketing?" in Health in Older Ages: The Causes and Consequences of Declining Disability among the Elderly. David Cutler and David Wise, eds. University of Chicago Press.

Farber, Henry and Helen Levy. 2000. "Recent Trends in Employer-Sponsored Health Insurance Coverage: Are Bad Jobs Getting Worse?" Journal of Health Economics. 19:1, 93-119.

Golosov, Mikhail and Aleh Tysvinski. 2006. "Designing Optimal Disability Insurance: A Case for Asset Testing.” Journal of Political Economy. April, 114:2, pp. 257-79.

Gruber, Jonathan and Jeffrey D. Kubik. 1997. "Disability Insurance Rejection Rates and the Labor Supply of Older Workers.” Journal of Public Economics. April, 64:1, pp. 1-23.

Gruber, Jonathan and Jeffrey D. Kubik. Forthcoming (2005). "Health Insurance Coverage and the Disability Insurance Application Decision.” Journal of Public Economics.

Hennessey, John and Janice Dykacz. 1993. "A Comparison of the Recovery Termination Rates of Disabled-Worker Beneficiaries Entitled in 1972 and 1985." Social Security Bulletin. Summer, 56:2, pp. 58-69.

Juhn, Chinhui, Kevin M. Murphy and Robert H. Topel. 2002. “Current Employment, Historically Contemplated.” Brookings Papers on Economic Activity. 1, pp. 79-116.

Katz, Lawrence F. and David H. Autor. 1999. "Changes in the Wage Structure and Earnings Inequality,” in Handbook of Labor Economics. Vol. 3A. Orley Ashenfelter and David Card, eds. Amsterdam: Elsevier-North-Holland.

Lando, M., A. Farley and M. Brown. 1982. "Recent Trends in the Social Security Disability Insurance Program." Social Security Bulletin. 45:8, 3-14. .

Lewin Group. 1998. "Policy Evaluation of the Effect of Legislation Prohibiting the Payment of Disability Benefits to Individuals Whose Disability is Based on Drug Addiction and Alcoholism: Interim Report.” Unpublished report by the Lewin Group, Inc., June 21.

Manton, Kenneth G. and XiLiang Gu. 2001. "Changes in the Prevalence of Chronic Disability in the United States Black and Non-Black Population Above Age 65, from 1982 to 1999.” Proceedings of the National Academy of Sciences. May 8, 98:11, pp. 6354-59. 
Organisation for Economic Co-operation and Development. 2003. “Transforming Disability into Ability: Policies to Promote Work and Income Security for Disabled People.” Paris: OECD.

Parsons, Donald O. 1980. “The Decline in Male Labor Force Participation.” Journal of Political Economy. February, 88:1, pp. 117-34.

Parsons, Donald O. 1991. “The Health and Earnings of Rejected Disability Insurance Applicants: Comment.” American Economic Review. December, 81:5, pp. 1419-26.

Rupp, Kalman and Charles Scott. 1988. "Determinants of Duration on the Disability Rolls and Program Trends," in Growth in Disability Benefits: Explanations and Policy Implications. Kalman Rupp and David Stapleton, eds. Kalamazoo, MI: Upjohn Institute for Employment Research, pp. 139-76.

Social Security Administration. Various years. Annual Statistical Supplement.

Social Security Administration. Various years. Annual Statistical Report on the Social Security Disability Program. Available at <http://www.ssa.gov/policy/docs/statcomps/>

Social Security Advisory Board. 1998. "How SSA’s Disability Programs Can Be Improved.” Available at <http://www.ssab.gov/Publications/Disability/report6.pdf>.

Social Security Advisory Board. 2001. "Charting the Future of Social Security’s Disability Programs: The Need for Fundamental Change.” Available at $<$ http://www.ssab.gov/Publications/Disability/disabilitywhitepap.pdf $>$.

Social Security Advisory Board. 2003. “The Social Security Definition of Disability.” Available at <http://www.ssab.gov/documents/SocialSecurityDefinitionOfDisability_002.pdf>.

Social Security Administration Board of Trustees. 2005. "The 2005 Annual Report of the Board of Trustees of the Federal Old-Age and Survivors Insurance and Disability Insurance Trust Funds.” Available at <http://www.ssa.gov/OACT/TR/TR05/tr05.pdf>.

Stapleton, David C. and Richard V. Burkhauser. 2003. The Decline in Employment of People with Disabilities: A Policy Puzzle. Kalamazoo, MI: Upjohn Institute for Employment Research.

United States Census Bureau. 2005. "Current Population Reports, P23-209: 65+ in the United States: 2005.” Washington, DC: U.S. Government Printing Office. Available at

United States Department of Health and Human Services. "2005 CMS Statistics.” <http://www.cms.hhs.gov/MedicareMedicaidStatSupp/downloads/2005_CMS_Statistics.pdf>.

United States General Accounting Office. 1997. "Social Security Disability: SSA Must Hold Itself Accountable for Continued Improvement in Decision-Making.” GAO-97-102 Washington, DC: US Government Printing Office. Available at <http://www.gao.gov/ >. 
United States General Accounting Office. 2003. “SSA Disability Decision Making: Additional Steps Needed to Ensure Accuracy and Fairness of Decisions at the Hearing Level." GAO-04-14. Washington, DC: US Government Printing Office. Available at $<$ http://www.gao.gov/>.

United States House of Representatives, Committee on Ways and Means. Various years. Overview of Entitlement Programs. Some recent versions are available at: $<$ http://aspe.hhs.gov/2000gb/> or at <http://aspe.hhs.gov/2002)>.

Verkuil, Paul and Jeffrey Lubbers. 2002. “Alternative Approaches to Judicial Review of Social Security Disability Cases: A Report to the Social Security Advisory Board.” Available at < http://www.ssab.gov/Publications/Disability/VerkuilLubbers.pdf > . (Accessed 10/28/2005).

Weaver, R. Kent, Robert Y. Shapiro and Lawrence R. Jacobs. 1995. "Poll Trends: Welfare.” Public Opinion Quarterly. 59:4, p. 606-27. 
Figure 1. Disability Insurance Recipiency and Award Rates per Adult Ages 25 - 64, 1957 - 2005 (Excludes Dependents)

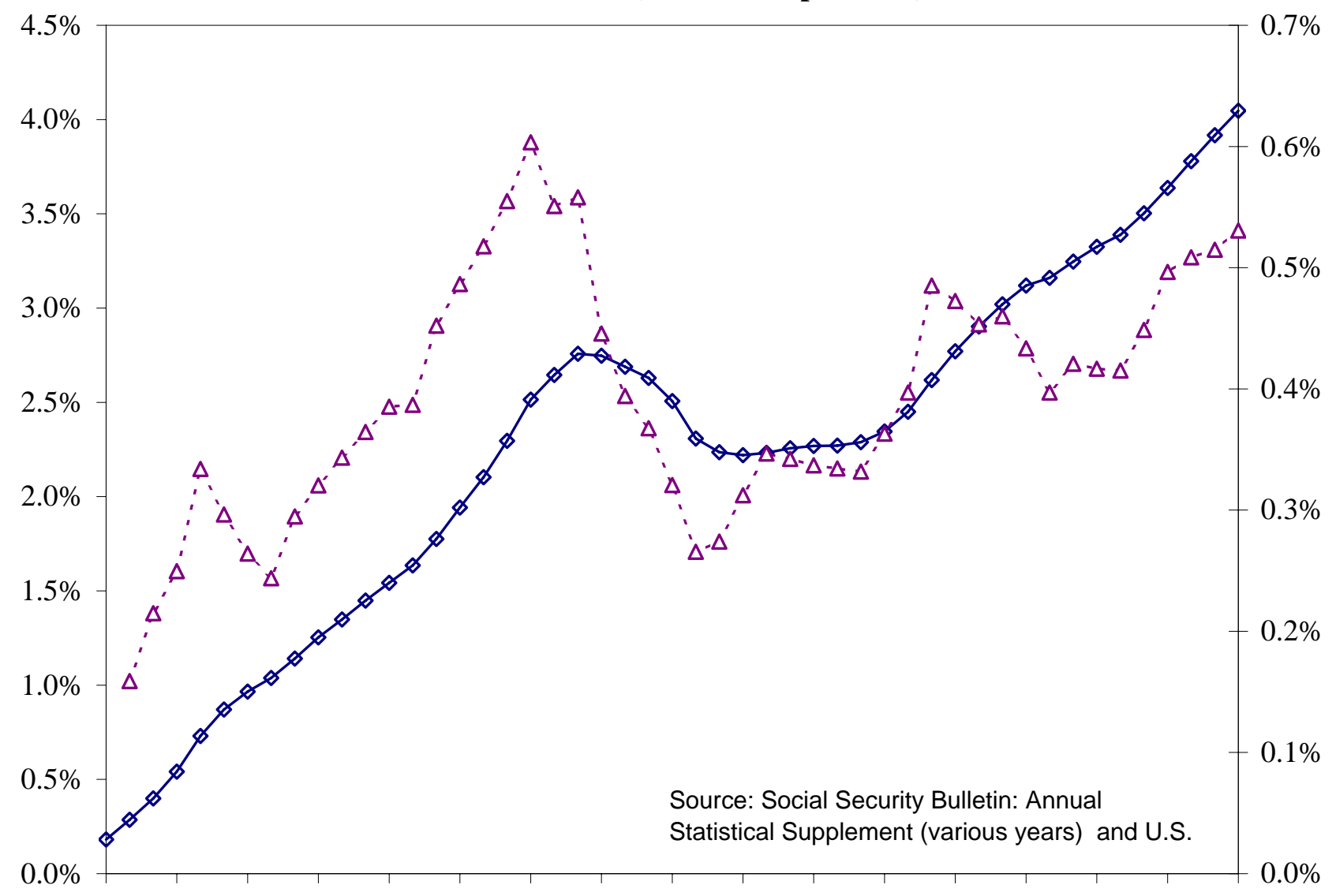

19571960196319661969197219751978198119841987199019931996199920022005

$\multimap$ ๑ Percent Receiving Benefits (left axis) $\quad$ - - - - Award Rate per Population (right axis) 
Figure 2. DI Termination Rates per 1,000 Beneficiaries by Reason, 1963 - 2004

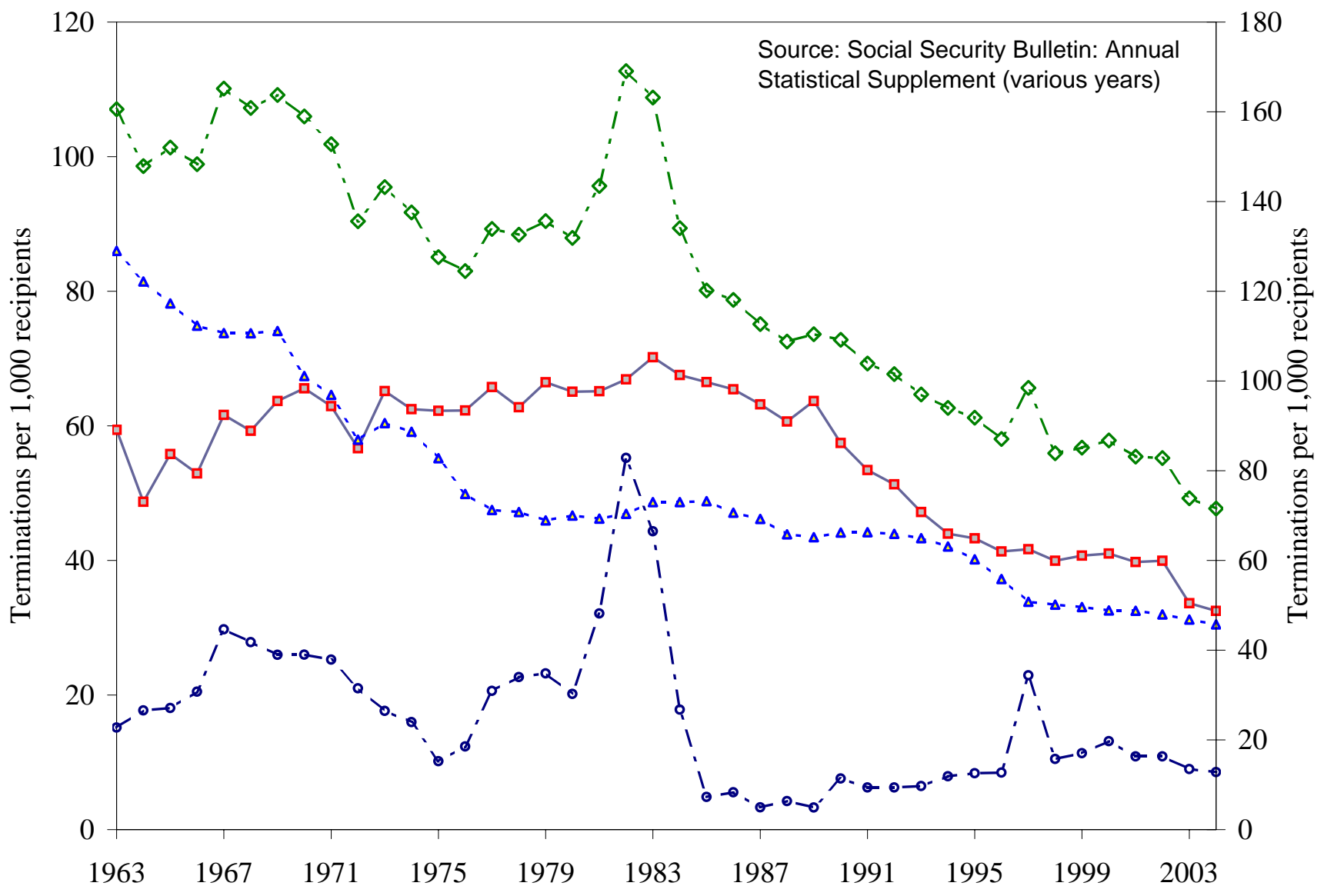

$\longrightarrow$ Retirements - - - - - Deaths - - - - Medical disqualifications - $-\diamond-$ All (right-axis) 
Figure 3. Illustration of the Impact of Earnings Inequality and Indexation on Disability Insurance Benefits in 1980 and 2000

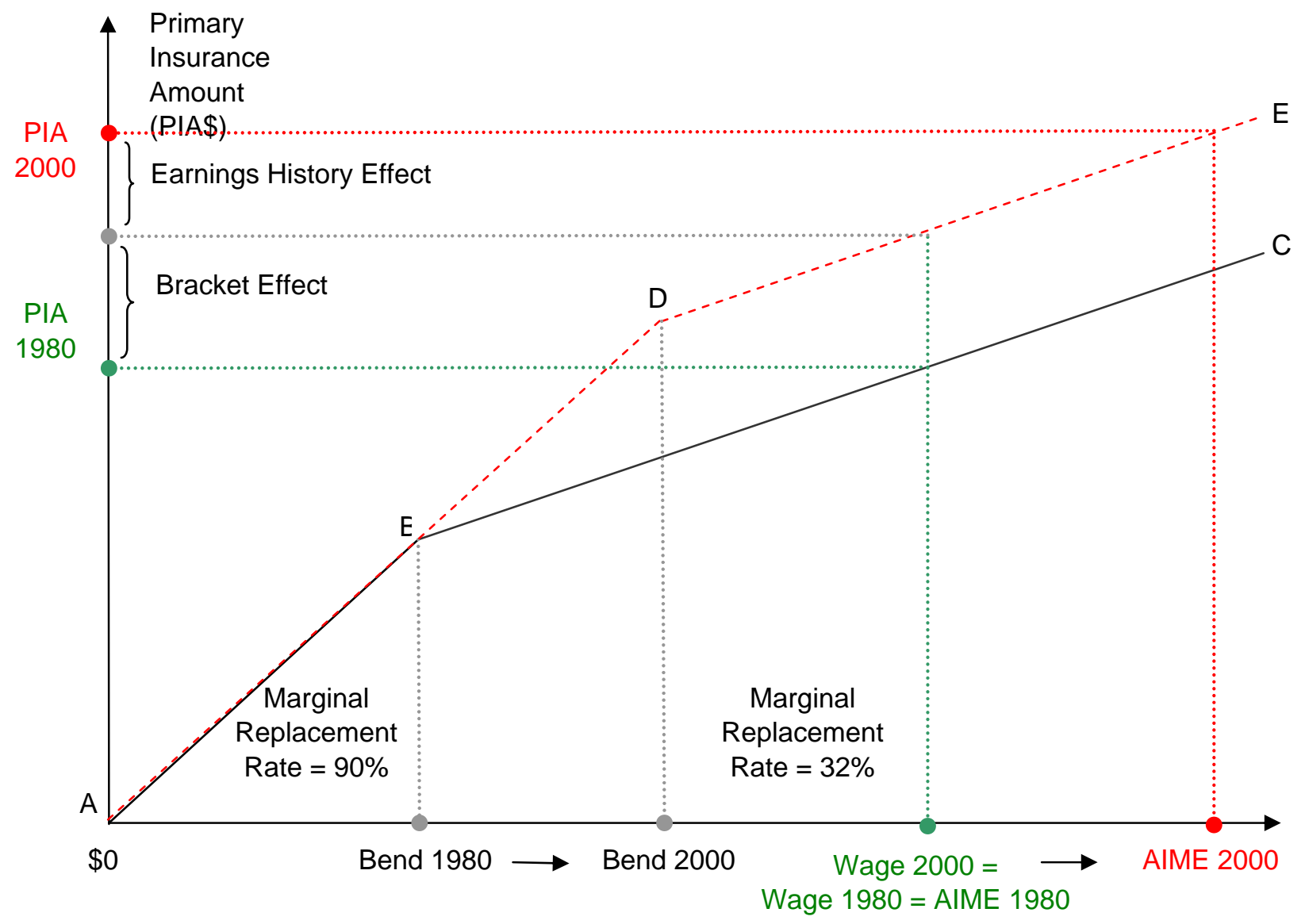

Average Indexed Monthly Earnings (AIME\$) 
Figure 4: DI Applications per Non-Elderly Adult and the U.S. Unemployment Rate: 19782004

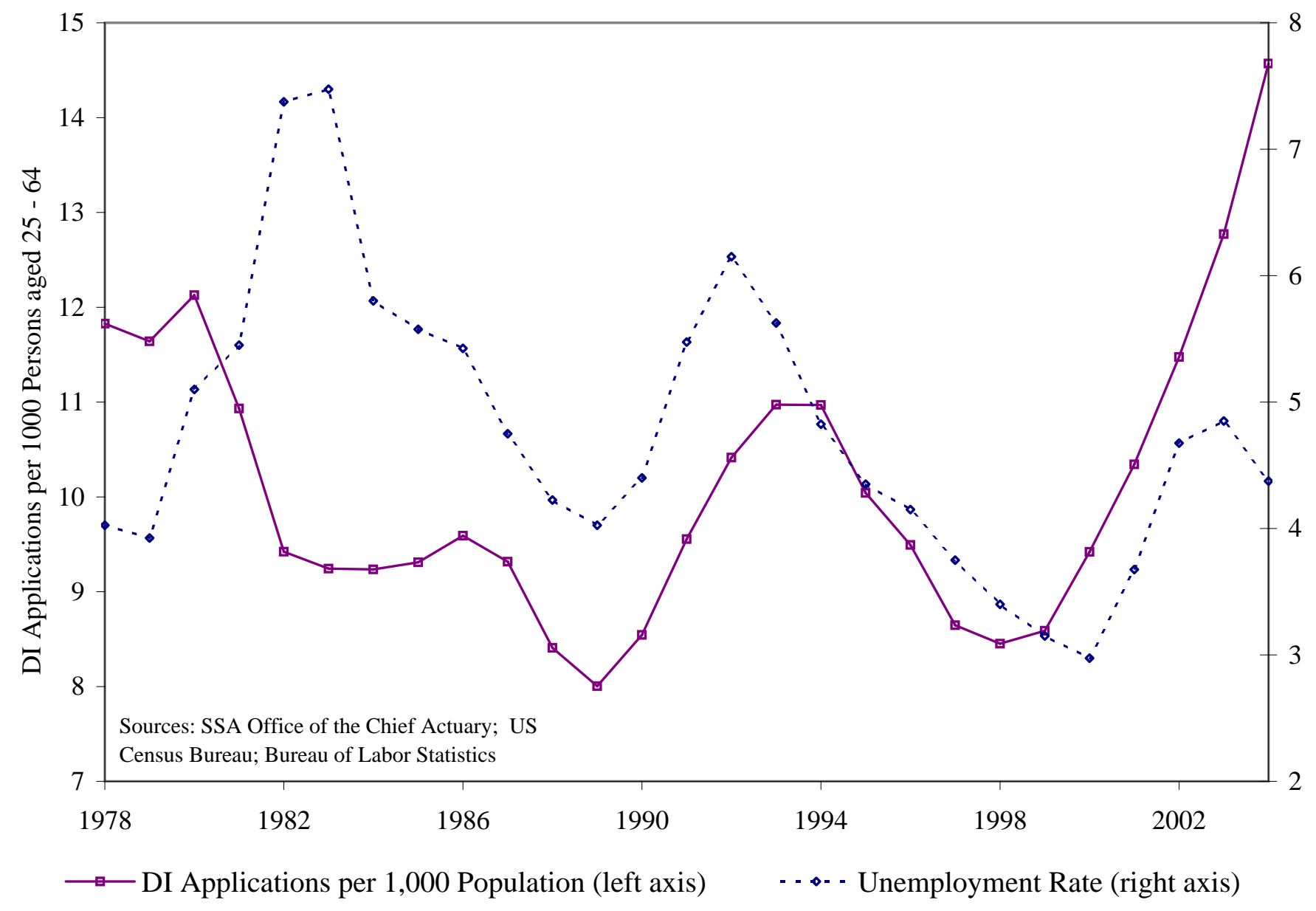


Table 1: SSDI Awards by Diagnosis Group, 1983 and 2003

\begin{tabular}{|c|c|c|c|c|c|c|}
\hline \multirow[b]{2}{*}{ Diagnosis Group } & \multicolumn{2}{|c|}{$\begin{array}{l}\text { Number of } \\
\text { Dl Awards }\end{array}$} & \multicolumn{2}{|c|}{$\begin{array}{c}\text { Awards per } \\
1,000 \text { Insured }\end{array}$} & \multicolumn{2}{|c|}{ Share of Awards } \\
\hline & 1983 & 2003 & 1983 & 2003 & 1983 & 2003 \\
\hline Heart disease & 68,352 & 85,896 & 0.65 & 0.60 & $21.9 \%$ & $11.4 \%$ \\
\hline Cancer & 52,379 & 70,942 & 0.49 & 0.49 & $16.8 \%$ & $9.4 \%$ \\
\hline Mental disorders & 50,633 & 191,679 & 0.48 & 1.33 & $16.3 \%$ & $25.4 \%$ \\
\hline Musculoskeletal disorders (e.g. back pain) & 41,782 & 199,014 & 0.39 & 1.38 & $13.4 \%$ & $26.3 \%$ \\
\hline Nervous system & 26,203 & 64,369 & 0.25 & 0.45 & $8.4 \%$ & $8.5 \%$ \\
\hline Respiratory system & 17,978 & 32,007 & 0.17 & 0.22 & $5.8 \%$ & $4.2 \%$ \\
\hline Injuries & 15,646 & 28,612 & 0.15 & 0.20 & $5.0 \%$ & $3.8 \%$ \\
\hline Endocrine system (e.g., diabetes) & 14,904 & 23,407 & 0.14 & 0.16 & $4.8 \%$ & $3.1 \%$ \\
\hline All other & 23,613 & 59,780 & 0.22 & 0.42 & $7.6 \%$ & $7.9 \%$ \\
\hline Total & 311,490 & 755,706 & 2.94 & 5.25 & $100.0 \%$ & $100.0 \%$ \\
\hline
\end{tabular}

Award rate defined as awards per 1000 individuals insured for DI in each year. Data on awards by diagnosis obtained from the Annual Statistical Report on the Social Security Disability

Insurance Program, 2003. Data on the number of people insured for DI obtained from the SSA's Office of the Actuary. 
Table 2. Estimated Changes in SSDI Earnings Replacement Rates for Males Ages 30 to 61 by Earnings Percentile, 1984 to 2002

\begin{tabular}{|c|c|c|c|c|}
\hline & \multicolumn{2}{|c|}{ Wage Replacement Rate } & \multicolumn{2}{|c|}{$\begin{array}{c}\text { Adding Fringe } \\
\text { Benefits, Medicare }\end{array}$} \\
\hline & 1984 & 2002 & 1984 & 2002 \\
\hline & \multicolumn{4}{|c|}{ Males $30-39$} \\
\hline 10th & $48.4 \%$ & $59.4 \%$ & $60.6 \%$ & $85.7 \%$ \\
\hline 50th & $36.2 \%$ & $41.9 \%$ & $35.4 \%$ & $44.4 \%$ \\
\hline \multirow[t]{2}{*}{ 90th } & $24.1 \%$ & $26.1 \%$ & $22.5 \%$ & $24.7 \%$ \\
\hline & \multicolumn{4}{|c|}{ Males $40-49$} \\
\hline 10th & $51.1 \%$ & $55.1 \%$ & $62.7 \%$ & $76.9 \%$ \\
\hline 50th & $33.5 \%$ & $43.3 \%$ & $32.7 \%$ & $44.4 \%$ \\
\hline \multirow[t]{2}{*}{ 90th } & $19.4 \%$ & $24.8 \%$ & $18.4 \%$ & $23.3 \%$ \\
\hline & \multicolumn{4}{|c|}{ Males $50-61$} \\
\hline 10th & $55.2 \%$ & $64.0 \%$ & $67.8 \%$ & $86.0 \%$ \\
\hline 50th & $34.7 \%$ & $45.9 \%$ & $34.1 \%$ & $46.4 \%$ \\
\hline 90th & $19.0 \%$ & $23.7 \%$ & $18.2 \%$ & $22.4 \%$ \\
\hline
\end{tabular}


Table 3: Rate of Disablity Insurance Receipt by Gender, Race,

Age and Education: 1984 and 2004

\begin{tabular}{|c|c|c|c|c|}
\hline & \multicolumn{2}{|c|}{ Males } & \multicolumn{2}{|c|}{ Females } \\
\hline & 1984 & 2004 & 1984 & 2004 \\
\hline & \multicolumn{4}{|c|}{ Actual DI Enrollment } \\
\hline 25-64, All & $3.0 \%$ & $4.3 \%$ & $1.4 \%$ & $3.5 \%$ \\
\hline 25-39, All & $0.9 \%$ & $1.3 \%$ & $0.4 \%$ & $1.1 \%$ \\
\hline 40-54, All & $2.8 \%$ & $4.3 \%$ & $1.2 \%$ & $3.6 \%$ \\
\hline 55-64, All & $9.4 \%$ & $10.9 \%$ & $4.2 \%$ & $8.3 \%$ \\
\hline \multicolumn{5}{|l|}{ SIPP DI Enrollment } \\
\hline 25-64, All & $2.8 \%$ & $3.5 \%$ & $1.8 \%$ & $3.5 \%$ \\
\hline 25-64, White & $2.7 \%$ & $3.4 \%$ & $1.6 \%$ & $3.2 \%$ \\
\hline 25-64, Black & $4.6 \%$ & $5.5 \%$ & $3.5 \%$ & $5.4 \%$ \\
\hline 25-39, HS Dropout & $2.3 \%$ & $2.5 \%$ & $1.0 \%$ & $2.7 \%$ \\
\hline 40-54, HS Dropout & $5.4 \%$ & $7.8 \%$ & $3.8 \%$ & $6.5 \%$ \\
\hline 55-64, HS Dropout & $14.8 \%$ & $19.7 \%$ & $9.1 \%$ & $12.7 \%$ \\
\hline 25-39, HS Graduate & $0.9 \%$ & $2.0 \%$ & $0.5 \%$ & $1.9 \%$ \\
\hline 40-54, HS Graduate & $2.3 \%$ & $3.4 \%$ & $1.3 \%$ & $3.8 \%$ \\
\hline 55-64, HS Graduate & $6.7 \%$ & $9.6 \%$ & $3.6 \%$ & $8.1 \%$ \\
\hline 25-39, College Degree & $0.1 \%$ & $0.4 \%$ & $0.2 \%$ & $0.5 \%$ \\
\hline 40-54, College Degree & $1.2 \%$ & $1.5 \%$ & $0.6 \%$ & $1.9 \%$ \\
\hline 55-64, College Degree & $2.7 \%$ & $3.7 \%$ & $1.8 \%$ & $5.0 \%$ \\
\hline \multicolumn{5}{|c|}{$\begin{array}{l}\text { Source: Authors' tabulations from SSA administrative data (first four rows) and the } \\
\text { first wave of the } 1984 \text { and } 2004 \text { versions of the Survey of Income and Program } \\
\text { Participation (all other rows). SIPP samples includes adults ages } 25 \text { to } 64 \text {, with } \\
\text { samples sizes of } 25,591 \text { in } 1984 \text { and } 57,412 \text { in } 2004 \text {. High school droupout } \\
\text { category includes those who have not completed a } 12 \text { th grade education or passed } \\
\text { the GED. College degree includes those with } 2 \text { or more completed years of } \\
\text { schooling in the } 1984 \text { survey and those with an Associate's Degree or greater in the } \\
2004 \text { survey. The HS Graduate category includes all other individuals. Age } \\
\text { denotes respondent's age in the first month of the SIPP wave. }\end{array}$} \\
\hline
\end{tabular}

